\title{
Corporate Social Responsibility of Pharmaceutical Industry in Brazil
}

\author{
Cândido Ferreira Silva Filho \\ Samuel Carvalho De Benedicto \\ Cibele Roberta Sugahara \\ Marcos Ricardo Rosa Georges \\ Pontifícia Universidade Católica de Campinas \\ Centro de Economia e Administração \\ Rua Professor Doutor Euryclides de Jesus Zerbini, 1516 \\ Campinas - SP - Brazil
}

\begin{abstract}
Social responsibility has been attracting increasing attention from corporations. The objective of this article is to identify how the concept of social responsibility is understood by firms in the pharmaceutical sector, to compare the communication of social responsibility by Brazilian and foreign companies, and to characterize the articulation of social responsibility with business strategy. The results show that the companies studied have found convergences and divergences in CSR practices. Brazilian pharmaceutical companies seem more concerned to identify their partners in CSR projects, compared to foreign companies. Another divergence concerns the declaration of the purpose of the organization, where foreign companies make more explicit their commitment to social and environmental responsibility. A critical aspect in the communication of social responsibility is the identification of partners and the results of projects and programmes on CSR and sustainability. With regard to administrative practices, convergence predominates in relation to the communication of social responsibility.
\end{abstract}

Keywords: sustainability; social responsibility; pharmaceutical sector strategy; communication,

\section{Introduction}

Social responsibility has been attracting increasing attention from corporations. This is because society expects companies to contribute to social and environmental development, and not just pursue profits. Today, social responsibility has become a matter of survival, with social actions being part of corporate competitive strategies, as shown by Carroll (1991) and Carroll and Hoy (1984). Carroll and Hoy (1984) argue that the perenniality of corporations in today's market depends, among other factors, on engagement with sustainability and social responsibility initiatives in the face of the serious human and business problems threatening the planet. Therefore, social responsibility as part of competitive strategy can contribute to business results (Carroll and Hoy 1984, TurcsanyiandSisaye 2013).

However, despite the economic relevance and contributions of the pharmaceutical sector to the quality of life of the population, only few studies have dealt with corporate social responsibility and the strategies adopted by companies in the sector in the practice of this concept. Further research can contribute to the improvement of this sector in the quest for sustainability.

Pharmaceutical firms operating in Brazil have undergone significant changes since the 1990s. Two important changes in Brazilian legislation were decisive: ratification of the agreement on Trade-Related Aspects of Intellectual Property Rights (TRIPS), and the Generic Drug Act of 1999 (ISSE, 2011). According to the Brazilian Research-based Pharmaceutical Manufacturers Association - Interfarma (2017) in 2015, Brazil was 7th in the world market for medicines and it is estimated that by 2020 the country will be the 5 th in the market.

Hence, the research questions are: how do firms in the pharmaceutical industry communicate their social responsibility? Do foreign and national firms communicate social responsibility in a similar way? Is there a link between social responsibility and business strategy? 
The objective of this study is to identify how the concept of social responsibility is understood by firms in the pharmaceutical sector, to compare the communication of social responsibility by Brazilian and foreign companies, and to characterize the articulation of social responsibility with business strategy.

The specific objectives are as follows:

(i) Describe the treatment provided by companies in the pharmaceutical sector, both Brazilian and foreign, through their corporate website, of social responsibility;

(ii) To know the perception of corporate social responsibility in the pharmaceutical sector through the inclusion on the corporate website of the code of ethics and / or conduct, the communication of social responsibility actions and their results, web availability of social responsibility reports and mention of social responsibility in the mission statement and company values;

(iii) Compare the social responsibility actions of foreign firms with those of firms with origin of capital in Brazil; and

(iv) Verify the articulation of social responsibility projects and programmes with the business strategy.

\section{Literature Review}

\subsection{CSRconcept}

According to Carroll (1999), the modern era of social responsibility began in the 1950s with the thinker Howard R. Bowen, author of Social Responsibilities of the Businessman (1953). Bowen argued that social responsibility refers to desirable actions in relation to the goals and values of society. It is a truth that should guide business.

Davis (1960), on the other hand, understood that social responsibility deals with the actions and decisions of entrepreneurs who surpass, at least partially, the economic and technical interests of the firm. William C. Frederick (1960) and Joseph W. McGuire (1963) contributed to the improvement of the concept of responsibility by incorporating the notion of business ethics and corporate citizenship.

Moura-Leite and Padgett (2011) comment on the criticisms of the concept of social responsibility. Friedman (1970) argued that the only social responsibility in business was to increase profits, in an open competition, free and without fraud. Finally, social actions are acceptable only if justified in the self-interest of companies. In Carroll's (1979) interpretation, social problems need to be identified and the company needs to choose a philosophy of responding to problems of this nature.

Carroll $(1979,1991)$ clarified that social responsibility admits several dimensions. It involves, in addition to economic responsibility, legal, ethical and discretionary (or philanthropic) components. What the company does for itself and what the company does for others is of interest. In this sense, economic viability is not something that exclusively interests the company, but the whole society. This is because the economic dimension generates the resources that enable the development of other social responsibility actions. This understanding of the social responsibilities can be expressed through a pyramid, as shown in figure 1 .

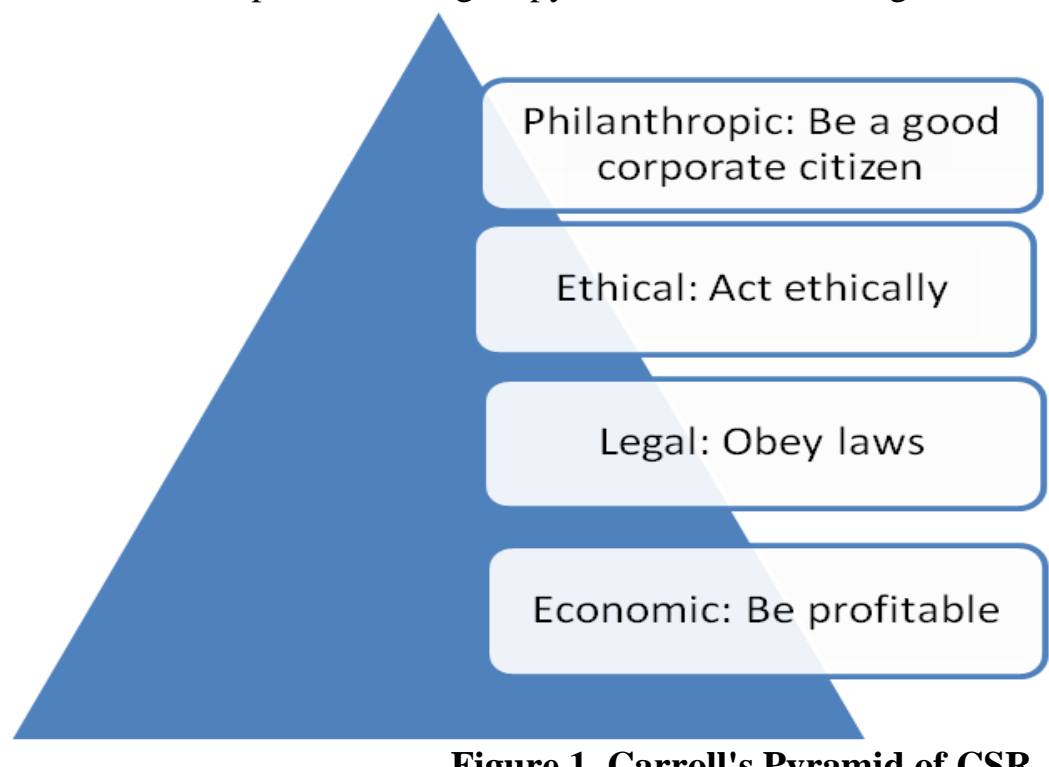

Figure 1. Carroll's Pyramid of CSR 
Moura-Leite and Padgett (2011) and Carroll (1999) comment that since the 1980s, research on social responsibility has been successful, with the reformulation of concepts, theories and explanatory models. Thus, social responsibility came to be perceived and promoted by consumers, companies, governments and international organizations. This is the case, for example, of the Commission of the European Communities which presented its concept of social responsibility in a Green Paper (2001): Corporate social responsibility is essentially a concept whereby companies decide voluntarily to contribute to a better society and a cleaner environment. [...] This responsibility is expressed towards employees and, more generally towards all stakeholders affected by business and which in turn may influence its success (COM2001, p.4).

According to Carroll and Shabana (2010), social responsibility has become part of the core business function of firms, enabling them to increase their competitive advantage. The authors point out that the arguments for social responsibility are integrated in the "core business" concernsof creating a competitive advantage,creating win-win relationships, reducing costs and risks, and strengthening the firm's legitimacy and reputation.

Trust is the mediating variable that shapes the relationship between social responsibility and firm performance. Thus, the appropriate social responsibility strategy seems to be one that is simultaneously aimed at improving relations with stakeholders and, at the same time, improving social well-being, as proposed by Barnett (2007). In fact, it is not possible to separate firms from the society in which they operate. Strategies and other economic objectives depend on the social environment in which the firm is inserted. Porter and Kramer (2006) argue that the correct strategy of social responsibility is one in which there is a convergence between economic and social objectives. Srour (2005) argues that through pressure from civil society, part of the added value of the company ends up being converted into social gains. Therefore, a socially responsible company must seek profit and, further, implement policies that improve the quality of life of society as a whole.

Therefore, social responsibility presupposes a voluntary contribution to a better society and a more sustainable environment. In addition, social responsibility is not restricted to fulfilling legal obligations — it implies going beyond. It concerns being attentive to all those impacted by the company and which, in turn, can affect their results. Therefore, social responsibility focuses on the community; the firm, as part of a larger system, must contribute to society's survival and progress.

\subsection{Social responsibility and strategy}

As Carroll and Shabana (2010) demonstrated, social responsibility is directly linked to business strategy. Barnett (2007) andFaria and Sauerbronn (2008) argue that CSR actions are justified for a number of reasons such as: the building of competitive advantages, matrix orientation in the case of multinational companies, strategic vision of long-term survival, image improvement, market development, decreased tax burden, values of internal solidarity, response to incentives offered by government and other organizations, as well as values of a religious or moral nature. Thus, social responsibility actions can be what the company does best and its source of competitive advantage.

It is clear that there is a strategic motivation for corporate social responsibility actions either to create a "competitive advantage" or as part of that strategy, that is, to respond to the threats and opportunities of the environment as a means to increase competitiveness, thereby improving its institutional image. The studies by Galbraeth (2009) and McManus (2008) find that the alignment of social responsibility with company strategy occurs worldwide.

Orlitzky, Siegel and Waldman (2011) claim that three theoretical approaches predominate: cost-benefit analysis, which is used as a strategic tool to optimize afirm's social responsibility activities; transaction cost economics, which makes explicit the cost of stakeholder management; and the resource-based view. When a firm uses its resources and capabilities to provide goods with some social characteristic, it finds consumers and stakeholders who value this attribute. Thus, social responsibility can be employed as part of a differentiation strategy at the product, business and corporate levels.

Therefore, social responsibility is part of the business strategy and, to that end, it must generate value or competitive advantage so that the firm can benefit from positive financial results, growth of market share, positive image, among others. It is essential to consider social responsibility as part of the business strategy, insofar as it is linked to the concept of sustainable development. 
Harjoto (2017) has also shown that firms with higher ethical values, reflected by social responsibility activities, have a lower probability of fraud and, in the event of it, it is less serious. Thus, by strengthening moral values among senior executives and employees, by encouraging social responsibility activities, firms help society minimize the problems of fraud. This is how the firm's reputation grows, enabling it to achieve better financial results.

\subsection{Social responsibility and strategy in the pharmaceutical industry}

In view of the economic relevance of the US pharmaceutical industry, Cook, LaVan and Zilic (2018) decided to make it the subject of their studies. The authors sought, among other things, to compare the perception of pharmaceutical firms about their own social responsibility with that of other stakeholders (press and general public). The authors concluded that there are opportunities for improvement because, for the firms studied, social responsibility was concentrated on economic factors. They also evidenced that firms need to do more in terms of communicating social responsibility.

Min, Desmoulins-Lebeault and Esposito (2017) studied the contributions of social responsibility to business value by adopting the triple bottom line approach, which involves environmental, social and economic aspects. They found that CSRadds value and needs to be understood as a long-term investment because it strengthens ties with stakeholders such as clients, government, investors and activists, creating positive relationships that enhance reputation and profitability.

Among the various sectors of the economy, the pharmaceutical industry has significant size globally, with various global corporations. The global presence in a changing world led Droppert and Bennett (2015) to study the social responsibility strategies of pharmaceutical multinationals. Specifically, the authors sought to understand how social responsibility strategies are articulated with business results. They demonstrated that there is an incipient understanding of the effects of social responsibility on businessbecause, among other things, there is a lack of indicators that allow better measurement of results.

Smith (2008) studied the social responsibility practices of the firms GlaxoSmithKline (GSK) and Bayer Corporation. According to the author, "stakeholders" require companies to act in the best interests of society. Efforts to improve responsiveness to society's demands enable the development of intangible strategic assets such as reputation, employee know-how and corporate culture. Therefore, social responsibility raises the perceived value of companies, contributing to business success and greater profits in the long run.

\section{Method}

\subsection{Research features}

The research was characterized, in the first place, as qualitative. The current study is also exploratory. This study can also be classified as descriptive because it describes the perception of pharmaceutical companies about social responsibility and its articulation with the business strategy.

Furthermore, this study is founded on a bibliographical and documentary research. Gil (2008) states that bibliographic and documentary research methods are similar,and that the difference between the two lies in the nature of the sources. While bibliographical research is mainly based on the contributions of various authors on a given subject, documentary research is based on materials that have not yet received an analytical treatment or that can still be re-elaborated according to the research objectives (Gil 2008, p.45).

\subsection{Data collection}

Dabic et al. (2016) analysed the literature with the purpose of knowing the practices of corporate social responsibility in the various sectors of the economy. The authors identified 302 articles reporting on such practices published in 99 different academic journals between 1995 and 2014. They found that studies on corporate social responsibility are unevenly distributed and that the issues studied and the methods used vary widely across industries.

Among the various means for communicating a firm's involvement with CSR, the current study privileges the websites. By communicating their principles, values and practices of social responsibility to stakeholders, companies hope to create a favourable public image, contributing to sales and profit growth, and, among other goals, attracting investors. 
Therefore, numerous surveys use websites as data sources, such as those conducted by Sousa FilhoWanderley, Lucian, Kooy(2014), CasteloBranco, Delgado, Sá, Sousa (2014), Tang and Li (2009), and Wanderley, Lucian, Farache, Sousa Filho (2008). Finally, it is possible to study CSR through its communication through websites.

To assess the social responsibility data available on corporate websites, the set of indicators called CSR Information Disclosure on the Web (CSRIDOW) proposed by Sousa Filho et al. (2014) and Wanderley et al. (2008) was used. Hence, the indicators used are: i) mention of social responsibility in the corporate website,ii) available code of ethics and / or conduct,iii) communication of social responsibility projects and programmes,iv)respective partners, $v$ ) results of social responsibility projects and programmes,vi) availability of social responsibility reports on the web, and vii) mention of social responsibility in the mission statement and company values.

This research was carried out based on the public information published on the firms' websites. To collect the data, the websites in the Portuguese language of the largest pharmaceutical companies operating in Brazil were visited.

Data collection occurred in April 2018 on the Portuguese websites of the 19 pharmaceutical companies that appear on the list of the 1,000 largest Brazilian companies and published by Examemagazine in May 2017. As a result, in 2017, there were 19 (nineteen) selected companies: Pfizer; Hypermarcas (HyperaPharma); Roche; Novartis; Sanofi-Aventis; EMS Sigma Pharma; Eurofarma; Aché; Abbott; LaboratórioCristália; Zoetis; UniãoQuímicaFarmacêutica; Neo Química; Medley; Prati-Donaduzzi; B. Braun; FQM; ApsenFarmacêutica; and Bristol-Myers (Editora Abril, 2016).

\subsection{Hypothesis test}

In order to verify the influence of the origin of the capital of the pharmaceutical company on the disclosure of social responsibility, the Chi-square test was performed. The test is nonparametric. When the differences between the observed and expected frequencies (calculated from observed frequencies) are very small, close to zero, there is no association between the variables. The Chi-square test makes it possible to test the following hypotheses:

Null hypothesis (H0). Brazilian and foreign companies are expected to report social responsibility in a similar way (statistical equality hypothesis). In this case, the observed frequencies are not different from the expected frequencies. There is no difference between frequencies.

Alternative hypothesis (H1). Brazilian and foreign companies communicate social responsibility differently. The frequencies observed are different from the expected frequencies. The deviations are significant.

It is necessary to obtain two statistics called $\chi^{2}$ calculated and $\chi^{2}$ tabulated. The calculated $\chi^{2}$ is obtained from the observed and expected data. The tabulated $\chi^{2}$ depends on the number of degrees of freedom and the level of significance adopted. Decision making is done by comparing the two values of $\chi^{2}$ :

If $\chi 2$ calculated is $>$ or $=\chi 2$ tabulated, we reject $\mathrm{H} 0$; and

If $\chi^{2}$ calculated is $<\chi 2$ tabulated, $\mathrm{H} 0$ is accepted

Therefore, a hypothesis is rejected when there is a lowprobability that a given sum of deviations will occur by chance.

In order to carry out the test, all 19 companies in the pharmaceutical industry listed among the 1,000 largest companies in Brazil by the Exame magazine were surveyed. A total of 152 observations were made, relating to eight different categories. In order to compare Brazilian and foreign companies, the data were grouped into seven categories in a total of 14 observations. Therefore, it is a relatively large sample, allowing the application of the $\chi^{2}$ test.

\section{Analysis of Results and Discussion}

\subsection{Communication of social responsibility}

In analysing the website of the 1,000 largest Canadian companies, Basil and Erlandson (2008) proposed that the most successful companies based on profit and total revenue have more social responsibility activities on their website. A similar result was observed in the Brazilian pharmaceutical industry. The firms with more social responsibility activities are among the eight largest companies in the sector in terms of net sales. Among the 19 companies surveyed, only one (5\%) reached the maximum score in the evaluated items, as shown in Table 1.

In other words, only one company mentions social responsibility (environmental, sustainability or corporate) on its website. 
It includes in its vision, mission or principles or values its commitment to social responsibility, communicates the projects and partners involved in social responsibility projects and, importantly, the results of these projects; makes available on the corporate website sustainability and / or Global Reporting Initiative (GRI) reports, indicating that it monitors and evaluates the results of social responsibility projects, and has a code of ethics and / or conduct to manage the relations between the internal and external parts of the organization. However, the largest pharmaceutical company in the Brazilian market obtained lower scores among the largest companies surveyed (Table 1), showing, based on the information available on the corporate website, few social responsibility activities. This is surprising, since larger companies tend to disclose more information about social responsibility projects and programmes than smaller companies (Wanderleyet al., 2008), because the activities of large companies have a greater impact on society and the environment, and therefore more information is required of large companies, both by society and media (AndrikopoulosandKriklani, 2013).

Table 1Social responsibility in Brazilian and foreign pharmaceutical companies in Brazil (by size)

\begin{tabular}{|c|c|c|c|c|c|c|c|c|}
\hline Firm & $\begin{array}{l}\text { Capital } \\
\text { origin }\end{array}$ & $\begin{array}{l}\text { Mention } \\
\text { SR on } \\
\text { website }\end{array}$ & $\begin{array}{l}\text { Code of Ethics } \\
\text { communication }\end{array}$ & $\begin{array}{l}\text { Communication of } \\
\text { SR projects }\end{array}$ & $\begin{array}{l}\text { SR project } \\
\text { partners }\end{array}$ & $\begin{array}{l}\text { SR } \\
\text { projects } \\
\text { results }\end{array}$ & $\begin{array}{l}\text { Sustainability } \\
\text { report or GRI }\end{array}$ & $\begin{array}{l}\text { SR mission, } \\
\text { values, } \\
\text { principles }\end{array}$ \\
\hline $\begin{array}{l}\text { Hypermarcas } \\
\text { (HyperaPharma) }\end{array}$ & Brazil & $\bullet$ & $\bullet$ & & & & & \\
\hline Pfizer & Foreign & $\bullet$ & & $\bullet$ & $\bullet$ & $\bullet$ & $\bullet *$ & $\bullet$ \\
\hline Roche & Foreign & $\bullet$ & $\bullet$ & $\bullet$ & & $\bullet$ & $\bullet * *$ & $\bullet$ \\
\hline Novartis & Foreign & $\bullet$ & $\bullet$ & $\bullet$ & & $\bullet$ & $\bullet *$ & \\
\hline Sanofi-Aventis & Foreign & $\bullet$ & $\bullet$ & $\bullet$ & & $\bullet$ & $\bullet$ & $\bullet$ \\
\hline $\begin{array}{ll}\text { EMS } & \text { Sigma } \\
\text { Pharma } & \\
\end{array}$ & Brazil & $\bullet$ & & - & $\bullet$ & $\bullet$ & & \\
\hline Eurofarma & Brazil & $\bullet$ & $\bullet$ & $\bullet$ & & $\bullet$ & $\bullet * *$ & $\bullet$ \\
\hline Aché & Brazil & $\bullet$ & $\bullet$ & $\bullet$ & - & $\bullet$ & - & $\bullet$ \\
\hline Abbott & Foreign & & $\bullet$ & & & & $\bullet *$ & \\
\hline $\begin{array}{l}\text { LaboratórioCristáli } \\
\text { a }\end{array}$ & Brazil & $\bullet$ & & $\bullet$ & & $\bullet$ & & \\
\hline Zoetis*** & Foreign & $\bullet$ & & $\bullet$ & - & $\bullet$ & & \\
\hline $\begin{array}{l}\text { UniãoQuímicaFarm } \\
\text { acêutica }\end{array}$ & Brazil & $\bullet$ & $\bullet$ & $\bullet$ & $\bullet$ & & & \\
\hline Neo Química & Brazil & - & & - & - & - & & \\
\hline Medley & Foreign & $\bullet$ & - & $\bullet$ & $\bullet$ & $\bullet$ & & \\
\hline Prati-Donaduzzi & Brazil & - & & $\bullet$ & $\bullet$ & & & \\
\hline B. Braun & Foreign & $\bullet$ & - & $\bullet$ & $\bullet *$ & $\bullet *$ & $\bullet *$ & $\bullet$ \\
\hline FQM & Foreign & $\bullet$ & & - & & & & \\
\hline ApsenFarmacêutica & Brazil & - & - & & & & & - \\
\hline Bristol-Myers & Foreign & $\bullet$ & $\bullet$ & - & $\bullet$ & & $\bullet *$ & $\bullet$ \\
\hline
\end{tabular}

(*) Available in English on the website

$(* *)$ provides form /email for GRI request.

(***) Animal welfare.

Source: created by the authors with survey data.

As can be seen in Table 1, only one company does not mention social responsibility on itswebsite, either on the homepage or in any section dealing with this issue.

In fact, among the 19 companies studied, ten have information or linkssuch as "social responsibility", "corporate responsibility", "sustainability", "corporate citizenship" on the homepage, emphasizing more social responsibility than the other companies. Note from Table 1 that all companies with capital originated in Brazil have sections dedicated to social responsibility. They use these sections to report on partnerships, projects and programmes supported. Another means for communicating social actions is through the publication of news on the company's website. In the column of firms with foreign origin of capital, only one (5\%) firm does not communicate through its corporate website its support for programmes and projects focused on social responsibility.

Social responsibility is characterized by concrete actions that bring benefits to society, the environment and the internal public to the company. In relation to projects and programmes, pharmaceutical companies emphasize support for health and education. Sustainable management practices receive less emphasis. Examining the content of the pages on social responsibility, we verified that only one company related, alongside projects and programmes aimed at the community and society in general, the concrete actions directed to its internal public. However, the details of the projects and programmes are limited. 
Also, pharmaceutical companies in Brazil do not use their corporate website to communicate their policies onthe fair treatment of employees, such as anti-discrimination initiatives of gender, race, age and others, and equal opportunities for training and promotion. With regard to strategies to stimulate the participation of society, we find that some companies post a form and / or e-mail on their website relating to the projects and proposals of partnerships, as well as criteria for project selection and an indication of the areas with priority social impact.

As far as the partners involved in social responsibility projects are concerned, nine (47\%) of the companies surveyed mention them on the corporate website. Brazilian companies seem more concerned with identifying the partners who benefited from social responsibility projects. Thus, six (31\%) companies with national capital identify the partners against three (16\%) foreign companies.

A critical aspect of the communication of social responsibility concerns the results of projects and programmes. Among the companies surveyed, seven (37\%) companies, four (21\%) of which Brazilian and three (16\%) foreign, did not provide any information about the results of social responsibility projects and programmes (Table 1).

After examining the corporate website of companies, we can affirm that there are opportunities for improving communication aboutthe results of social actions. Communicating in a satisfactory way means, among other things, providing information on the project implementation period, the institutions and the number of people benefited, presenting testimonials of the beneficiaries, the income generated, the number of volunteers, the financial resources applied in the project, among others. Finally, the communication of results is an opportunity for the firm to demonstrate all its involvement in social action.

Another difference between Brazilian and foreign companies is the availability of the sustainability report and / or Global Reporting Initiative (GRI). Only three (16\%) firms make the GRI available in Portuguese on the corporate website (or provide an e-mail or link to fill out a GRI application form), two (11\%) foreign firms and one (5\%) Brazilian company (Table 1).

It is interesting to note that five foreign pharmaceutical firms make the GRI available in English. This reveals, on the one hand, the concern of foreign firms with detailing social actions. On the other hand, the availability of the GRI in English alone may be linked to the perception that companies have of the Brazilian consumer. In this sense, foreign companies are forced to demonstrate to the world their contribution to a better planet. But we hypothesize that, in the view of these companies, the Brazilian consumer is not interested in corporate social responsibility. Hence, the absence of sustainability reports in Portuguese. This hypothesis could be tested in future studies

The code of conduct and business ethics sets the standards of ethical behaviour applied to employees and also to third parties such as suppliers and customers. In the pharmaceutical industry, this code is not communicated by seven (37\%) companies, four (21\%) companies with origin of capital in Brazil and another three (16\%) with origin of capital abroad (Table 1). Among the companies studied, three have a link on the homepage for this code, and for the others it is placed in a section such as "About us", "Who we are", "Compliance", "Institutional" and others.

Foreign companies seem more concerned with the communication of the code of conduct and ethics, compared to companies with origin in Brazil, as among the 12 companies that communicate the code of conduct and ethics, eight (42\%) are foreign, and only four (21\%) come from Brazil (Table 1).

The data show that eight (42\%) companies, among the 19 studied, use their statement of purpose (mission, vision, principles and values) to express their commitment to social responsibility.

Foreign pharmaceutical firms use their declaration of purpose more intensely than Brazilian companies to communicate their commitment to social responsibility. Among the companies studied, five (26\%) foreign companies, in declaring their purpose, manifest their social commitment, as do three (16\%) Brazilian firms.

The results suggest a variety of ways to communicate social responsibility on corporate websites. According to the expectations derived from the literature review, companies appear to be attentive to the demands of stakeholders, acting in the best interests of society. Nonetheless, it has been shown that there is scope for improvement, mainly through the identification of partners and the results of social responsibility and sustainability projects and programmes, as well as the dissemination of sustainability reports, making it possible to respond effectively to society's demands, which contributes to raising the firm's reputation and business success in the long run. 


\subsection{A comparison between Brazilian and foreign pharmaceutical firms}

The unit of analysis was the company's corporate website. Each item evaluated (mention of social responsibility on the corporate website, code of ethics and / or conduct, communication of social responsibility projects and programmes, identification of partners in social responsibility projects and programmes, presentation of results of projects and programmes of social responsibility, web availability of social responsibility reports, mention of social responsibility in the mission statement and company values) has been assigned "one" point. The score achieved by Brazilian (or foreign) companies, with the highest possible score, in each evaluated item, were transformed into a percentage. Table 2 shows the percentage of Brazilian (and foreign) companies that reported the evaluated item through the corporate website:

Table 2 Social responsibility of Brazilian and foreign pharmaceutical companies in Brazil, for each evaluated item $(\%)$

\begin{tabular}{|l|l|l|}
\hline Item & Brazil & Abroad \\
\hline Mention of SR on the site & 100 & 90 \\
\hline Code of Ethics & 55.6 & 70 \\
\hline Communication of SR projects & 77.8 & 90 \\
\hline Partners of SR projects & 55.6 & 30 \\
\hline Results of SR projects & 55.6 & 60 \\
\hline GRI & 11.1 & 10 \\
\hline SR mission, values, principles & 33.3 & 50 \\
\hline
\end{tabular}

Source: Authors' survey data

The $\chi 2$ statistic for the above data is 0.028083 , the tabulated $\chi 2$ statistic with significance level equals 0.05 (or $5 \%$ ) and six degrees of freedom is 1,635 indicating that the independence hypothesis (H0) cannot be rejected. Therefore, the hypothesis that Brazilian and foreign companies do not give a similar treatment for the communication of social responsibility is accepted.

A similar result was observed in the literature. CasteloBranco et al. (2014), when comparing the communication of social responsibility among companies in Sweden and Spain, found that the difference between the two countries is very small, without any statistical significance, although Swedish firms appear to offer a greater variety of CSR-related information.

Tang and Li (2009), studying the communication of SRby Chinese and global companies in China, found that there are no significant differences in how these companies communicate their social responsibility. In fact, the authors noted that the understanding of social responsibility by most Chinese and global companies encompasses economic responsibility, and legal, ethical and discretionary components, as proposed by Carroll $(1979,1991)$.

However, Wanderley et al. (2008) found that communication of social responsibility was heavily influenced by the country of origin. The data available on the corporate website on the code of ethics, social responsibility projects, project results, partnerships, reports, corporate values, and the presence of the expression social responsibility or sustainable development on the corporate website enabled the authors to reject the null hypothesis ( $\mathrm{H} 0)$ and confirm the alternative hypothesis ( $\mathrm{H} 1)$. hus, the results of thatstudy suggest that Brazilian and foreign companies are aligning their administrative practices in relation to the dissemination of social responsibility, which can be attributed to globalized markets, as proposed by Cormier and Magnan (2003). Effectively, the results indicate that the differences in communication between Brazilian and foreign companies in Brazil are not statistically significant.

\subsection{Social responsibility and strategy}

The literature suggests that social responsibility is directly linked to strategy, as demonstrated, for example, by Carroll and Shabana (2010), Faria and Sauerbronn (2008) and Barnett (2007). Social responsibility strengthens ties with clients, government, investors, activists and others, building positive relationships and improving reputation. If reputation grows, it increases the perceived value of the firm, which contributes to its survival, business success and greater profits in the long run. Social responsibility can be the means by which the company derives its competitive advantage. However, as shown in Table 1, companies in the industry under study have not demonstrated the strengthening of ties with stakeholders. 
Few companies identified the partners involved in social responsibility projects and programmes, the results of social and environmental actions, and published sustainability reports and / or Global Reporting Initiative (GRI). In the absence of this information, no further comment can be made on the relationship between social responsibility and corporate strategy. However, through GRI, the company can clarify the role of social responsibility and sustainability in its competitive strategy, as well as the value it intends to return to employees, shareholders and society. Sustainability reports also enable stakeholders to be involved in defining priority issues in terms of social responsibility and sustainability.

Sustainability reports provide information on all social, educational, cultural and sporting projects and programmes that create value for the firm and society. In addition, they may clarify the fair treatment of employees, equal opportunities in career development, policies aimed at preventing discrimination based on gender, race, age, religion and others, as well as ethical relationships with suppliers and customers.

In addition, GRI sustainability reports identify the pillars of economic, environmental and social sustainability, and their connection to strategy. Through these documents, society has access, among other things, to the firm's social and environmental investments, both from its own resources and from incentives, or to the partners involved in various social and environmental actions.

Sustainability reports also make it possible to clarify the commercial and ethical practices and instruments of governance, of the people and managements involved in social responsibility and sustainability. These documents can also address the innovations relevant to society that have been or are being supported by the firm. Finally, as companies in the pharmaceutical industry disseminate sustainability reports, it becomes possible to demonstrate the relationship between social responsibility, sustainability and strategy. This is a relevant topic for future studies

\section{Discussion and future research}

The present study examined the communication of social responsibility by pharmaceutical firms in Brazil. The concern about social responsibility is global, but it was evidenced that most Brazilian and foreign firms in the pharmaceutical sectoroperating in Brazil disregardthis issue. We have found convergences and divergences in SR practices. Convergentaspects include the mention of social responsibility on the corporate website, and the lack of disclosure of sustainability reports and / or GRI. On the other hand, Brazilian pharmaceutical companies seem more concerned to identify their partners in SR projects, compared to foreign companies. Another divergence concerns the declaration of the purpose of the organization, where foreign companies make more explicit their commitment to social and environmental responsibility. A critical aspect in the communication of social responsibility is the identification of partners and the results of projects and programmes on SR and sustainability, and the dissemination of sustainability reports. The corporate website of most companies is not very enlightening in relation to these requirements.

However, with regard to administrative practices, convergence predominates in relation to the communication of social responsibility. Statistical tests revealed that the differences in communication amongBrazilian and foreign pharmaceutical firms are not significant. The literature, as previously mentioned, proposes that social responsibility may be the means by which the company derives its competitive advantage. However, communication through the corporate website is not enlightening about the role of social responsibility and sustainability in the competitive strategy of the firms in this industry. With regard to future research, it is necessary to disclose the mechanisms that have resulted in the approximation of the administrative practices of Brazilian and foreign companies in the sector. Social responsibility is the result of culture, values and administrative and communication practices. Thus, it is necessary to understand the influence of these factors on social responsibility and sustainability practices, given the globalization of markets.

Another question for research concerns the content of sustainability reports and / or GRI. Future research can analyse sustainability reports with the purpose of demonstrating the articulation of social responsibility with corporate strategy. In addition, studies should address stakeholder perceptions of social responsibility and sustainability initiatives.

Finally, broadening the understanding of the phenomenon of social responsibility communication also requires monitoring in time and the qualitative evaluation of the content of the corporate website of the firms in the sector. Communication through the website refers to the image that the company wants to project. Hence, studies are necessary to describeand explainthe effective practices of pharmaceutical firms in Brazil. 


\section{References}

Andrikopoulos, A, Kriklani, N. 2013. Environmental disclosure and financial characteristics of the firm: the case of Denmark. CORP SOC RESP ENV MA, 20(1): 55-64.

Barnett, ML. 2007. Stakeholder influence capacity and the variability of financial returns to corporate social responsibility. ACAD MANAGE REV, 32(3): 794-816.

Basil, D.Z, Erlandson, J. 2008. Corporate social responsibility website representations: a longitudinal study of internal and external self-presentations, JMC, 14(2): 125-137.

Bowen, HR. 1953. Social responsibilities of the businessman. New York: Harper \& Row.

Carroll, AB. Sept 1999. Corporate Social Responsibility: Evolution of a Definitional Construct. BUS SOC, 38(3): 268-295.

Carroll, AB. 1991.The pyramid of corporate social responsibility: toward the moral management of organizational stakeholders, BUS HORIZONS, 4(4): 39-46.

Carroll, AB. Oct 1979. A Three-Dimensional Conceptual Model of Social. ACAD MANAGE REV, 4(4):497505.

Carroll, AB.; Hoy, F. 1984. Integrating Corporate Social Policy into Strategic management. JBS, 4(3): 48-57.

Carroll, AB, Shabana, KM. 2010. The Business Case for Corporate Social Responsibility: A Review of Concepts, Research and Practice. INT J MANAG REV, 12(1): 85-105.

CasteloBranco, M, Delgado, C, Sá, M, Sousa, C. Comparing CSR communication on corporate web sites in Sweden and Spain. BALT J MANAG, 9(2): 231-250, 2014.

Comissão das Comunidades Europeias. 2001. Livro Verde: promover um quadro europeu para a responsabilidade social das empresas [Green Book]. Brussels.

Cook, L, Lavan, H, Zilic, I. (2018). An exploratory analysis of corporate social responsibility reporting in US pharmaceutical companies. JCOM, 22(2):197-211.

Cormier, D, Magnan, M. 2003. Environmental reporting management: a continental European perspective. J ACCOUNT PUBLIC POL, 22(1): 43-62.

Dabic, M, Colovic, A, Painter-Morland, OL, Brozovic, S. 2016. Industry-specific CSR: analysis of 20 years of research. TEBR, 28(3): 250-273.

Davis, K. 1960. Can business afford to ignore social responsibilities? CALIF MANAGE REV, 2, 70-76.

Droppert, H, Bennett, S. 2015. Corporate social responsibility in global health: an exploratory study of multinational. GLOBALIZATION HEALTH, 11(15): 1-8.

Faria, A, Sauerbronn, FF. 2008. A responsabilidade social é uma questão de estratégia? Uma abordagem crítica. [Issocial responsibility a strategyissue? A criticalapproach] Revista de Administração Pública (RAP), Rio de Janeiro, 42(1): 07-33.

Frederick, WC. 1960. The growing concern over business responsibility. CALIF MANAGE REV, 2(4): 54-61.

Friedman, M. 1970 Sept 13. The social responsibility of business is to increase its profits. TNYTM.

Galbreath, J. (2009). Building corporate social responsibility into strategy. TEBR, 21(2):109-127.

Gil, A. C. 2008. Métodos e técnicas de pesquisa social [Methodsandtechniques in social research]. 6. ed. São Paulo: Atlas.

Harjoto, M. A. 2017. Corporate social responsibility and corporate fraud. SRJ, 13(4): 762-779.

Interfarma. 2017. Associação da Indústria Farmacêutica de Pesquisa

[Brazilian Research-based PharmaceuticalManufacturers Association.] Guia 2016 [2016 Guide].

Accessed 2017 June 22 https://www.interfarma.org.br/guia/impressora.

Isse, KF. 2011. A Indústria farmacêutica nacional e a importância dos medicamentos genéricos no seu desenvolvimento [The nationalpharmaceuticalindustryandtheimportanceofgenericmedication in its development]. Master'sthesis. Porto Alegre (RS): Universidade Federal do Rio Grande do Sul.

McGuire, JW. 1963. Business and society. New York: McGraw-Hill.

McManus, T. 2008. The business strategy/corporate social responsibility “mash-up". JMD, 27(10): 1066-1085.

Editora Abril. Revista Exame. 2017. Ranking do setor farmacêutico em 2016. Accessed on 2017 Jun 21 http://mm.exame.abril.com.br/empresas/filtrar/2016/farmaceutico/Todos.

Min, M, Desmoulins-Lebeault, F, Esposito, M. 2017. Should pharmaceutical companies engage in corporate social responsibility? JMD, 36(1): 58-70.

Moura-Leite, RC, Padgett, RC. 2011. Historical background of corporate social responsibility. SRJ, 7(4):528-539. 
Orlitzky, M, Siegel, DS. Waldman, DA. 2011. Strategic Corporate Social Responsibility and Environmental Sustainability. Bus Soc, 50(1): 6-27.

Porter, ME, Kramer, MR. 2006. Strategy \& society: the link between competitive advantage and corporate social responsibility. HBR, 84 (12):78-92, 2006.

Smith, AD. Corporate social responsibility practices in the pharmaceutical industry, BSS, 9(6):306-315, 2008.

Souza Filho, JM, Wanderley, LSO, Lucian, R; Kooy, K. van der. Set/dez 2004. Comunicação da responsabilidade social empresarial em websites corporativos: estudo comparado com grandes empresas de países emergentes [Communication ofcorporate social responsibility in corporate websites: a comparativestudyonlargecompanies in emerging countries. GeAS, 3(3): 122-134.

Srour, RH. 2005. Poder, cultura e ética nas organizações: o desafio das formas de gestão. Rio de Janeiro, Elsevier.

Tang, L, LI, H. 2009. Corporate social responsibility communication of Chinese and global corporations in China. PUBLIC RELAT REV, 35:191-212.

Trivinos, ANS. 2010. Introdução à Pesquisa de Ciências Sociais [Introductiontotheresearchon Social Sciences]. São Paulo: Atlas.

Turcsanyi, J, Sisaye, S. 2013. Corporate social responsibility and its link to financial performance: Application to Johnson \& Johnson, a pharmaceutical company", WJSTSD, 10(1): 4-18.

Wanderley, LSO, Lucian, R, Farache, F, Sousa Filho, JM. 2008. Oct. CSR Information disclosure on the web: a context-based approach analysing the influence of country of origin and industry sector. JBE, 82: 369378. 